\title{
Drug-Induced Changes in Histamine and tele-Methylhistamine Levels in Mouse Peripheral Tissues
}

\author{
Shigeki KOYAMA, Ryozo OISHI, Shin SENOH and Kiyomi SAEKI* \\ Department of Pharmacology, Okayama University Medical School, \\ 2-5-1 Shikata-cho, Okayama 700, Japan
}

Accepted January 6, 1986

\begin{abstract}
To clarify the histamine (HA) dynamics in peripheral tissues, effects of drugs on the tissue $\mathrm{HA}$ and tele-methylhistamine $(\mathrm{t}-\mathrm{MH})$ levels were studied in mice. $\alpha$-Fluoromethylhistidine (50 mg/kg, i.p.) significantly decreased the $H A$ level in the stomach, but not in the liver, heart, ileum, submandibular gland and skin of mice. This compound had no significant effect on the $\mathrm{t}-\mathrm{MH}$ level in any tissue examined. In non-fasted and 24-hr fasted animals, the $\mathrm{t}-\mathrm{MH}$ level in the liver, heart and ileum was significantly increased by treatment with aminoguanidine (10 mg/kg, i.p.) plus pargyline $(65 \mathrm{mg} / \mathrm{kg}$, i.p.). However, in mice fasted for $48 \mathrm{hr}$, this treatment was ineffective in increasing the $\mathrm{t}-\mathrm{MH}$ level in the heart and ileum, suggesting that the t-MH level in some peripheral tissues is under the influence of the food intake. Even if $\mathrm{HA}$ is synthetized and then metabolized in the peripheral tissues, the size of the HA pool with a rapid turnover in each tissue except for the gastric tissue seems to be very small.
\end{abstract}

Histamine (HA) is present in almost all mammalian tissues. In general, the skin, lung and gastrointestinal tract are rich sources of HA (1, 2). It has been established that HA plays roles in anaphylaxis, acute inflammation and gastric secretion. However, the physiological roles of HA in most peripheral tissues are poorly understood.

Except for the brain (3-7) and stomach (4, 8, 9), a large majority of HA contained in most tissues appears to undergo a very slow turnover. However, Levine et al. (10) suggested the presence of a HA pool with a rapid turnover in the rat heart, and Håkanson et al. (11) suggested the presence of neuronal HA in the intestinal wall, which likewise may undergo a rapid turnover.

$\mathrm{HA}$ is synthetized from L-histidine by histidine decarboxylase and is metabolized through two pathways, i.e., oxidative deamination by diamine oxidase (DAO) to imidazoleacetic acid and methylation by HA$\mathrm{N}$-methyltransferase to tele-methylhistamine $(\mathrm{t}-\mathrm{MH})$ (12). $\mathrm{t}-\mathrm{MH}$ undergoes oxidative

\footnotetext{
* To whom all correspondence should be addressed.
}

deamination to tele-methylimidazoleacetic acid. In peripheral tissues, both DAO and monoamine oxidase (MAO) seem to be involved in this process $(13,14)$.

(S) $-\alpha$-Fluoromethylhistidine $(\alpha$-FMH) is a specific inhibitor of histidine decarboxylase (15). Aminoguanidine (16) and pargyline are inhibitors of DAO and MAO, respectively. Thus, information on the dynamics of endogenous HA in peripheral tissues may be obtained from the decrease in the tissue HA level induced by $\alpha$-FMH and the increase in the $\mathrm{t}-\mathrm{MH}$ level induced by the combination of aminoguanidine and pargyline. $\alpha-F M H$ and pargyline proved to be valuable tools for investigating the HA dynamics in the mammalian brain which lacks DAO $(3,4,6,7)$.

In an attempt to obtain further knowledge of the dynamics of HA and t-MH in the peripheral tissues, we used high performance liquid chromatography with fluorescence detection for the determination of the levels of amines in several peripheral tissues of mice given various treatments. This method for simultaneous determination of $\mathrm{HA}$ and $\mathrm{t}-\mathrm{MH}$ was developed by Tsuruta et al. (17). 


\section{Materials and Methods}

Chemicals and drugs: All chemicals used were at least of a guaranteed reagent grade. $\mathrm{HA}$ dihydrochloride was obtained from Wako Chemicals (Osaka, Japan); t-MH dihydrochloride and pros-methylhistamine dihydrochloride from Calbiochem-Behring Corp. (San Diego, CA, U.S.A.); aminoguanidine bicarbonate from Nakarai Chemicals (Kyoto, Japan); and pargyline hydrochloride from Sigma Chemical Co. (St. Louis, MO, U.S.A.). $\alpha-\mathrm{FMH}$ hydrochloride was a generous gift from Dr. J. Kollonitsch of Merck Sharp \& Dohme Research Laboratories (Rahway, NJ, U.S.A.).

Animals: Male ddY mice weighing 25-30 g (Shizuoka Laboratory Animal Center, Hamamatsu, Japan) were housed in groups in a room controlled at $22 \pm 2{ }^{\circ} \mathrm{C}$. Food and water were provided ad libitum. When fasted, the animals were placed in cages for 24 or $48 \mathrm{hr}$ before killing, with access only to water. Aminoguanidine, pargyline and $\alpha$-FMH were dissolved in $0.9 \%$ saline and injected i.p. in doses of $10 \mathrm{mg}$ free base $/ \mathrm{kg}, 65 \mathrm{mg}$ free base $/ \mathrm{kg}$, and $50 \mathrm{mg}$ free base $/ \mathrm{kg}$, respectively. $\alpha$-FMH was injected $12 \mathrm{hr}$ before and aminoguanidine and pargyline were injected $4 \mathrm{hr}$ before the mice were killed. When the effect of orally administered HA was studied, $\mathrm{HA}$ dissolved in saline was given in a dose of $10 \mathrm{mg}$ free base/animal, using a stomach cannula.

Determination of $\mathrm{HA}$ and $\mathrm{t}-\mathrm{MH}$ : Mice were killed by cervical dislocation, the tissues (liver, heart, ileum, stomach, skin and submandibular gland) immediately removed, washed in cold saline, weighed and homogenized in $10 \mathrm{ml}$ of $0.4 \mathrm{~N}$ perchloric acid with an appropriate amount (15 ng-2 $\mu \mathrm{g})$ of pros-methylhistamine as the internal standard. The homogenate was frozen and stored at $-20^{\circ} \mathrm{C}$ until assay. The $\mathrm{HA}$ and $\mathrm{t}-\mathrm{MH}$ were simultaneously determined by a slight modification (18) of the procedure of Tsuruta et al. (17). The high performance liquid chromatography system was composed of a LC-3A pump (Shimadzu, Kyoto, Japan), a RF-530 fluorescence spectromonitor (Shima$\mathrm{dzu})$ and a reverse-phase column $(150 \times 4.0$ $\mathrm{mm}$ inside diameter) packed with Chem- cosorb ODS-H (5 $\mu \mathrm{m}$, spherical form: Chemco Scientific Co., Osaka, Japan).

Statistical analysis: The data were evaluated for statistical significance by Student's t-test.

\section{Results}

Effects of $\boldsymbol{a}-\mathrm{FMH}$ on the tissue HA and t$\mathrm{MH}$ levels: The HA level in the stomach of 12-hr fasted mice significantly decreased $12 \mathrm{hr}$ after $\alpha$-FMH treatment, as compared with the saline-treated control group (Fig. 1). However, no significant changes in the HA level were observed in the liver, ileum, heart, submandibular gland and skin. $\alpha-\mathrm{FMH}$ had no significant effect on the t-MH level in any tissue examined.

Effects of aminoguanidine and pargyline on the tissue HA and t-MH levels: When the effects of aminoguanidine and pargyline on the tissue $\mathrm{HA}$ and $\mathrm{t}-\mathrm{MH}$ levels were studied
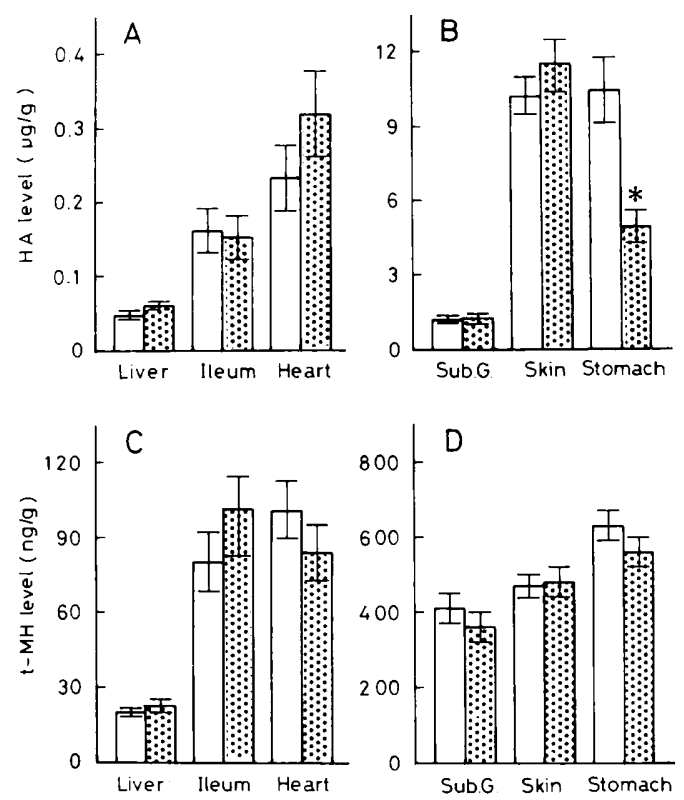

Fig. 1. Effect of $\alpha-F M H$ on the HA (A, B) and t$\mathrm{MH}$ (C, D) levels in the mouse peripheral tissues. $\alpha-\mathrm{FMH}(50 \mathrm{mg} / \mathrm{kg})$ or saline was injected i.p. $12 \mathrm{hr}$ after the start of fasting. and the animals were killed $12 \mathrm{hr}$ after injection. Open and stippled columns represent the saline- and $\alpha$-FMH-treated groups, respectively. Vertical bars are the S.E.M. $(n=6)$. Sub. G.: submandibular gland. *P<0.01 as compared with the saline-treated control group. 
in mice fasted for $24 \mathrm{hr}$, no changes in the HA level were produced by aminoguanidine and pargyline administered either separately or together (Table 1). However, the t-MH level in the liver, heart and ileum was significantly increased by the combined treatment with these drugs. Aminoguanidine administered alone significantly increased the $\mathrm{t}-\mathrm{MH}$ level in the liver.

Effects of fasting on the steady-state tissue levels of $\mathrm{HA}$ and $\mathrm{t}-\mathrm{MH}$ and the changes in these amine levels induced by aminoguanidine and pargyline: The gastric HA level in mice fasted for $48 \mathrm{hr}$ was sig-

Table 1. Effects of aminoguanidine and pargyline on the HA and $\mathrm{t}-\mathrm{MH}$ levels in the peripheral tissues of mice fasted for $24 \mathrm{hr}$

\begin{tabular}{|c|c|c|c|c|}
\hline & Saline & Pargyline & Aminoguanidine & $\begin{array}{l}\text { Aminoguanidine } \\
\text { +Pargyline }\end{array}$ \\
\hline \multicolumn{5}{|l|}{$\mathrm{HA}$} \\
\hline Liver $(n g / g)$ & $54.8 \pm 4.5$ & $43.0 \pm 6.0$ & $62.4 \pm 4.6$ & $42.8 \pm 5.2$ \\
\hline Heart (ng/g) & $277.5 \pm 78.7$ & $279.5 \pm 40.6$ & $305.8 \pm 32.9$ & $336.3 \pm 64.8$ \\
\hline Ileum (ng/g) & $195.1 \pm 58.1$ & $175.9 \pm 49.3$ & $204.8 \pm 54.1$ & $185.4 \pm 47.9$ \\
\hline Stomach $(\mu \mathrm{g} / \mathrm{g})$ & $8.44 \pm 1.28$ & $8.13 \pm 0.62$ & $9.86 \pm 0.94$ & $7.92 \pm 0.85$ \\
\hline Skin $(\mu \mathrm{g} / \mathrm{g})$ & $12.65 \pm 1.80$ & $10.25 \pm 0.81$ & $14.09 \pm 1.26$ & $11.05 \pm 1.60$ \\
\hline Submandibular gland $(\mu \mathrm{g} / \mathrm{g})$ & $1.32 \pm 0.22$ & $1.30 \pm 0.18$ & $1.44 \pm 0.15$ & $1.10 \pm 0.19$ \\
\hline \multicolumn{5}{|l|}{$\mathrm{t}-\mathrm{MH}$} \\
\hline Liver (ng/g) & $23.4 \pm 4.4$ & $30.7 \pm 3.0$ & $36.3 \pm 2.6^{*}$ & $55.9 \pm 8.2^{* *}$ \\
\hline Heart (ng/g) & $78.9 \pm 10.1$ & $88.8 \pm 7.8$ & $95.9 \pm 3.0$ & $136.2 \pm 4.5^{* *}$ \\
\hline Ileum (ng/g) & $83.7 \pm 6.4$ & $79.7 \pm 5.2$ & $109.2 \pm 12.1$ & $153.7 \pm 18.0^{* *}$ \\
\hline Stomach $(\mu \mathrm{g} / \mathrm{g})$ & $0.52 \pm 0.08$ & $0.54 \pm 0.05$ & $0.54 \pm 0.05$ & $0.52 \pm 0.06$ \\
\hline Skin $(\mu \mathrm{g} / \mathrm{g})$ & $0.46 \pm 0.02$ & $0.48 \pm 0.04$ & $0.51 \pm 0.03$ & $0.44 \pm 0.03$ \\
\hline Submandibular gland $(\mu \mathrm{g} / \mathrm{g})$ & $0.38 \pm 0.02$ & $0.39 \pm 0.03$ & $0.45 \pm 0.03$ & $0.48 \pm 0.05$ \\
\hline
\end{tabular}

Aminoguanidine $(10 \mathrm{mg} / \mathrm{kg})$ and pargyline $(65 \mathrm{mg} / \mathrm{kg})$ were injected i.p. separately or in combination $4 \mathrm{hr}$ before killing. Control mice received saline injection. Results are the means \pm S.E.M. of 6 mice. ${ }^{*} \mathrm{P}<0.05,{ }^{*} \mathrm{P}<0.01$ as compared with the saline-treated group.

Table 2. Effects of fasting on the steady-state tissue levels of $\mathrm{HA}$ and $\mathrm{t}-\mathrm{MH}$ and the changes in these amine levels induced by aminoguanidine and pargyline

\begin{tabular}{|c|c|c|c|c|}
\hline & \multicolumn{2}{|c|}{$\mathrm{HA}$} & \multicolumn{2}{|c|}{$\mathrm{t}-\mathrm{MH}$} \\
\hline & Saline & $\begin{array}{l}\text { Aminoguanidine } \\
+ \text { Pargyline }\end{array}$ & Saline & $\begin{array}{l}\text { Aminoguanidine } \\
+ \text { Pargyline }\end{array}$ \\
\hline \multicolumn{5}{|l|}{ Non-fasted } \\
\hline Liver (ng/g) & $62.5 \pm 15.2$ & $46.7 \pm 5.6$ & $17.0 \pm 1.9$ & $46.7 \pm 5.5^{*}$ \\
\hline Heart (ng/g) & $256.8 \pm 35.9$ & $230.3 \pm 28.9$ & $72.3 \pm 4.6$ & $102.8 \pm 4.1^{*}$ \\
\hline Ileum (ng/g) & $289.8 \pm 30.7$ & $373.2 \pm 10.9$ & $106.3 \pm 11.7$ & $209.5 \pm 26.0^{*}$ \\
\hline Stomach $(\mu \mathrm{g} / \mathrm{g})$ & $7.1 \pm 0.7$ & $6.8 \pm 0.7$ & $0.59 \pm 0.08$ & $0.53 \pm 0.07$ \\
\hline \multicolumn{5}{|l|}{ 48-hr fasted } \\
\hline Liver $(n g / g)$ & $71.5 \pm 8.7$ & $64.8 \pm 12.0$ & $27.6 \pm 1.5 t t$ & $49.8 \pm 1.9^{* *}$ \\
\hline Heart (ng/g) & $227.9 \pm 42.4$ & $239.9 \pm 30.9$ & $115.4 \pm 13.1^{\dagger}$ & $117.2 \pm 11.7$ \\
\hline Ileum (ng/g) & $210.1 \pm 63.4$ & $162.4 \pm 24.5+t t$ & $158.2 \pm 13.0 t$ & $121.9 \pm 7.1 t t$ \\
\hline Stomach $(\mu \mathrm{g} / \mathrm{g})$ & $14.3 \pm 1.9 \dagger t$ & $11.9 \pm 0.7 t+t$ & $0.75 \pm 0.06$ & $0.63 \pm 0.08$ \\
\hline
\end{tabular}

Mice were injected i.p. with aminoguanidine $(10 \mathrm{mg} / \mathrm{kg})$ plus pargyline $(65 \mathrm{mg} / \mathrm{kg})$ or saline $4 \mathrm{hr}$ before killing. Results are the means \pm S.E.M. of 6 mice. ${ }^{*} P<0.01$, ${ }^{*} P<0.001$ as compared with the corresponding saline-treated groups. $t P<0.05$, $t+P<0.01, t \dagger+P<0.001$ as compared with the non-fasted group. 
Table 3. Effects of oral administration of HA on the tissue HA and t-MH levels

\begin{tabular}{|c|c|c|c|}
\hline & $\begin{array}{l}\text { Saline } \\
\text { - Saline }\end{array}$ & $\begin{array}{l}\text { Saline } \\
-H A\end{array}$ & $\begin{array}{l}\text { Aminoguanidine } \\
+ \text { Pargyline } \\
-H A\end{array}$ \\
\hline \multicolumn{4}{|l|}{ HA } \\
\hline Liver (ng/g) & $54.0 \pm 14.3$ & $205.8 \pm 38.3^{* *}$ & $440.8 \pm 101.3^{* *}, \dagger$ \\
\hline Heart $(\mu \mathrm{g} / \mathrm{g})$ & $0.23 \pm 0.05$ & $1.10 \pm 0.27^{* *}$ & $6.37 \pm 1.03^{* * *+\dagger}$ \\
\hline Stomach $(\mu \mathrm{g} / \mathrm{g})$ & $11.5 \pm 1.1$ & $50.7 \pm 15.4^{*}$ & $37.1 \pm 9.5^{*}$ \\
\hline \multicolumn{4}{|l|}{$\mathrm{t}-\mathrm{MH}$} \\
\hline Liver (ng/g) & $20.8 \pm 5.9$ & $114.6 \pm 24.3^{* *}$ & $272.4 \pm 30.8^{* * *, \dagger}$ \\
\hline Heart $(\mu \mathrm{g} / \mathrm{g})$ & $0.09 \pm 0.02$ & $0.77 \pm 0.13^{* * *}$ & $1.19 \pm \quad 0.15^{* * *}$ \\
\hline Stomach $(\mu \mathrm{g} / \mathrm{g})$ & $0.69 \pm 0.08$ & $2.98 \pm 0.37^{* * *}$ & $6.58 \pm 1.50^{* *}, \dagger$ \\
\hline
\end{tabular}

Mice were injected i.p. with aminoguanidine $(10 \mathrm{mg} / \mathrm{kg})$ plus pargyline $(65 \mathrm{mg} / \mathrm{kg})$ or saline $4 \mathrm{hr}$ before killing, and they were administered p.o. with HA (10 mg free base/animal) or saline $3 \mathrm{hr}$ before. Results are the means \pm S.E.M. of 6 mice. ${ }^{*} P<0.05,{ }^{* *} P<0.01,{ }^{* *} P<0.001$ as compared with the salinepretreated and saline-treated group. $\mathrm{T} P<0.05$ as compared with the saline-pretreated and HA-treated group.

nificantly higher than the level in non-fasted mice (Table 2). However, fasting had no significant influence on the HA level in other tissues studied. The $\mathrm{t}-\mathrm{MH}$ level in the liver, heart and ileum was significantly increased by fasting.

In non-fasted mice, the t-MH level in the liver, heart and ileum was significantly increased by the treatment with aminoguanidine plus pargyline. Similar effects of the combined treatment with these drugs on the $\mathrm{t}-\mathrm{MH}$ level in these tissues were observed in mice fasted for $24 \mathrm{hr}$ (Table 1). However, in mice fasted for $48 \mathrm{hr}$, a significant increase in the $\mathrm{t}-\mathrm{MH}$ level was observed only in the liver, after the same treatment.

In 48-hr fasted mice treated with aminoguanidine plus pargyline, both $\mathrm{HA}$ and $\mathrm{t}-\mathrm{MH}$ levels in the ileum were markedly lower than the values in non-fasted mice given the same combined treatment.

Effects of the oral administration of HA on the tissue HA and $\mathrm{t}-\mathrm{MH}$ levels: This experiment was designed to determine whether dietary HA at least in part can escape metabolic changes and reach peripheral tissues. When mice were given orally $10 \mathrm{mg} /$ animal of HA $3 \mathrm{hr}$ before killing, the $\mathrm{HA}$ and $\mathrm{t}-\mathrm{MH}$ levels in the liver, heart and stomach significantly increased (Table 3). The increases in these amine levels were far more marked in mice pretreated $4 \mathrm{hr}$ before killing with aminoguanidine plus pargyline than in the saline-pretreated mice, except for the HA level in the stomach.

\section{Discussion}

The $\mathrm{t}-\mathrm{MH}$ level in the mouse stomach determined in the present study was in a range of the values obtained by Imamura et al. (19) who used the dansylation method.

In the present experiment, $\alpha-\mathrm{FMH}$ decreased the gastric HA level in 12-hr fasted mice by $53.3 \% 12 \mathrm{hr}$ after treatment. This is in good agreement with the result of Maeyama et al. (4). However, Bouclier et al. (9) reported that $\alpha$-FMH caused no change in the gastric HA level throughout the $24-\mathrm{hr}$ period after treatment in fasted pylorus-ligated rats. Such discrepancies may not be due to species differences but to the difference in $\mathrm{HA}$ turnover in the stomach between fed and fasted animals. This view is supported by the observation that $\alpha-\mathrm{FMH}$ was much less effective in decreasing the gastric HA level in fasted than in fed mice (data not shown). In the present study, a marked increase in the gastric HA level was observed in fasted mice. Kahlson et al. (8) showed that re-feeding fasted rats results in a decrease in the HA level in the gastric mucosa and the subsequent elevation of mucosal HA forming capacity. The results obtained in rats by Kahlson et al. (8) and Bouclier et al. (9) as well as our data in mice suggest that the gastric HA turnover in these fasted rodents is relatively slow and 
re-feeding results in the release of mucosal $\mathrm{HA}$ accumulated during fasting and there is a subsequent elevation of histidine decarboxylase activity.

$\alpha$-FMH did not decrease the HA level in the liver, heart, ileum, skin and submandibular gland, thereby suggesting that if such exists, the size of a rapidly turning over pool(s) for endogenous HA in these tissues is very small. However, Levine et al. (10) reported that histidine decarboxylase inhibitors, such as $\alpha$ hydrazinohistidine and NSD-1055 (brocresine) caused a significant decrease in the cardiac HA level in rats. $\alpha-F M H$ is a more potent and specific inhibitor of histidine decarboxylase than $\alpha$-hydrazinohistidine and NSD-1055 (15, 20). The reason for the discrepancy between our result and that of Levine et al. (10) is not clear.

In the present experimental conditions, $\alpha$ $\mathrm{FMH}$ had no significant influence on the $\mathrm{t}$ $\mathrm{MH}$ level in any of the peripheral tissues studied. Therefore, it is likely that the maintenance of the steady-state t-MH level in these tissues does not largely depend on methylation of the HA from a pool(s) with a rapid turnover present in the respective tissues, at least under the conditions studied. The observations made in the peripheral tissues are in contrast with the $\alpha-\mathrm{FMH}$ induced decrease in the $\mathrm{t}-\mathrm{MH}$ level in the brain $(6,7)$. t-MH formation from $\mathrm{L}-3$ methylhistidine by histidine decarboxylase has been noted in several mouse tissues (21). However, since $\alpha$-FMH did not decrease the $\mathrm{t}-\mathrm{MH}$ level in all the tissues studied, the contribution of this pathway may also be small in maintaining the $\mathrm{t}-\mathrm{MH}$ level.

In the present experimental conditions, the combined treatment with aminoguanidine and pargyline significantly increased the $\mathrm{t}$ $\mathrm{MH}$ level in the liver, heart and ileum of nonfasted and 24-hr fasted mice. No significant drug-induced increase in the $\mathrm{t}-\mathrm{MH}$ level was observed in the stomach, skin and submandibular gland. This may be due to a much higher steady-state $\mathrm{t}-\mathrm{MH}$ level in these tissues than in the liver, heart and ileum. The combined treatment with aminoguanidine and pargyline was ineffective in elevating the $\mathrm{t}$ $\mathrm{MH}$ level in the heart and ileum of mice fasted for $48 \mathrm{hr}$. Therefore, the $\mathrm{t}-\mathrm{MH}$ level in these tissues seems to be under the influence of the supply of $\mathrm{HA}$ and/or $\mathrm{t}-\mathrm{MH}$ from the blood, and food seems to be an important source of these blood amines. Especially in the ileum of 48-hr fasted mice, the HA level was lower than the level in non-fasted mice, the difference being significant in the group treated with aminoguanidine plus pargyline. When treated in the same way, the $\mathrm{t}-\mathrm{MH}$ level in the ileum of 48-hr fasted mice was significantly lower than the corresponding value in non-fasted mice. This suggests that HA in food is absorbed from the intestines and partly metabolized by DAO and MAO in these tissues. However, the reason for the significantly higher t-MH values in 48-hr fasted mice treated with saline is unknown. Besides, the endogenous HA released from the gastric tissue in response to the food intake may also contribute to the increase in the tissue $\mathrm{t}-\mathrm{MH}$ level in mice receiving the above drug treatment. Mice fed a HA-free food may be useful to estimate the contribution of endogenous HA to the maintenance of the tissue $\mathrm{t}-\mathrm{MH}$ level and the drug-induced increase in this amine level.

The HA and $\mathrm{t}-\mathrm{MH}$ levels in the liver, heart and stomach markedly increased after the oral administration of HA. Although the dose used was unphysiologically high, this finding suggests that HA contained in food can be absorbed from the gastrointestinal tract and transported to other peripheral tissues in the form of $\mathrm{HA}$ and/or $\mathrm{t}-\mathrm{MH}$.

In conclusion, the present results suggest that the HA pool with a rapid turnover in the tissues examined except for the stomach is extremely small, if such exists, and that the $\mathrm{t}-\mathrm{MH}$ level in some peripheral tissues of mice is influenced by the food intake.

\section{References}

1 Vugman, I. and Rocha e Silva, M.: Biological determination of histamine in living tissues and body fluids. In Handbook of Experimental Pharmacology, Edited by Rocha e Silva, M., Vol. 18/1, p. 81-115, Springer-Verlag, Berlin (1966)

2 Beaven, M.A.: Factors regulating availability of histamine at tissue receptors. In Pharmacology of Histamine Receptors, Edited by Ganellin, C.R. and Parsons, M.E., p. 103-145, John Wright \& Sons Ltd., Bristol (1982) 
3 Hough, L.B., Khandelwal, J.K. and Green, J.P.: Effects of pargyline or tele-methylhistamine and histamine in rat brain. Biochem. Pharmacol. 31 , 4074-4076 (1982)

4 Maeyama, K., Watanabe, T., Taguchi, Y., Yamatodani, A. and Wada, H.: Effect of $\alpha$ fluoromethylhistidine, a suicide inhibitor of histidine decarboxylase, on histamine levels in mouse tissues. Biochem. Pharmacol. 31, 23672370 (1982)

5 Maeyama, K., Watanabe, T., Yamatodani, A., Taguchi, Y., Kambe, H. and Wada, H.: Effect of $\alpha$-fluoromethylhistidine on the histamine content of the brain of $W / W^{v}$ mice devoid of mast cells: turnover of brain histamine. J. Neurochem. 41, 128-134 (1983)

6 Nishibori, M., Oishi. R. and Saeki, K.: Histamine turnover in the brain of different mammalian species: implications for neuronal histamine half-life. J. Neurochem. 43, 1544-1549 (1984)

7 Oishi, R., Nishibori, M. and Saeki, K.: Regional differences in the turnover of neuronal histamine in the rat brain. Life Sci. 34, 691-699 (1984)

8 Kahlson, G., Rosengren, E., Svahn, D. and Thunberg, R.: Mobilization and formation of histamine in the gastric mucosa as related to acid secretion. J. Physiol. (Lond.) 174, 400-416 (1964)

9 Bouclier, M., Jung, M.J. and Gerhart, F.: $\alpha$ Fluoromethyl histidine inhibition of histidine decarboxylase in pylorus ligated rat. Biochem. Pharmacol. 32, 1553-1556 (1983)

10 Levine, R.J., Sato, T.L. and Sjoerdsma, A.: Inhibition of histamine synthesis in the rat by $\alpha$-hydrazino analog of histidine and 4-bromo-3hydroxy benzyloxyamine. Biochem. Pharmacol. 14, 139-149 (1965)

11 Hăkanson, R., Wahlestedt, C., Westlin, L., Vallgren, S. and Sundler, F.: Neuronal histamine in the gut wall releasable by gastrin and cholecystokinin. Neurosci. Lett. 42, 305-310 (1983)

12 Schayer, R.W.: Catabolism of physiological quantities of histamine in vivo. Physiol. Rev. 39 116-126 (1959)

13 Kapeller-Adler, R, and Iggo, B.: Histamine and its derivatives in human urine. Biochim. Biophys. Acta 25, 394-402 (1957)

14 Linde!l, S.E. and Westling, H.: Enzymic oxidation of some substances related to histamine. Acta Physiol. Scand. 39, 370-384 (1957)

15 Kollonitsch, J., Patchett, A.A., Marburg, S., Maycock, A.L., Perkins, L.M., Doldouras, G.A., Duggan, D.E. and Aster, S.D.: Selective inhibitors of biosynthesis of aminergic neurotransmitters. Nature 274, 906-908 (1978)

16 Buffoni, F.: Histaminase and related amine oxidases. Pharmacol. Rev. 18, 1163-1199 (1966)

17 Tsuruta, Y., Kohashi, K. and Ohkura, Y.: Simultaneous determination of histamine and $\mathrm{N}^{\tau}$-methylhistamine in human urine and rat brain by high-performance liquid chromatography with fluorescence detection. J. Chromatogr. 224, 105-110 (1981)

18 Oishi, R., Itoh, Y., Nishibori, M. and Saeki, K.: $\Delta^{9}$-Tetrahydrocannabinol decreases turnover of brain histamine. J. Pharmacol. Exp. Ther. 232, 513-518 (1985)

19 Imamura, I., Watanabe, T., Maeyama, K., Kubota, A., Okada, A. and Wada, H.: Effect of food intake on urinary excretions of histamine, $\mathrm{N}^{-}$-methylhistamine, imidazole acetic acid and its conjugate(s) in humans and mice. J. Biochem. 96, 1931-1937 (1984)

20 Garbarg, M., Barbin, G., Rodergas, E. and Schwartz, J.C.: Inhibition of histamine synthesis in brain by $\alpha$-fluoromethylhistidine, a new irreversible inhibitor: in vitro and in vivo studies. J. Neurochem. 35, 1045-1052 (1980)

21 Schwartz, J.C., Rose, C. and Caillens, H.: Metabolism of methylhistamine formed through a new pathway: decarboxylation of L-3methylhistidine. J. Pharmacol. Exp. Ther. 184, 766-779 (1973) 